\title{
Croatia as a Sports Brand - Recognition of Croatian Sport and Athletes Among European Students
}

Preliminary communication _ DOI 10.22522/cmr20200153 _ received on 28 October 2019

UDK: 323.2(497.5):659.122

$796: 659$

.........

\section{Božo Skoko, PhD, Associate Professor}

Faculty of Political Science University of Zagreb, Zagreb, Croatia.

E-mail: bskoko@fpzg.hr

\section{Dejan Gluvačević, PhD}

Josip Juraj Strossmayer University of Osijek, Osijek, Croatia.

E-mail: dejan.gluvacevic@hotmail.com (corresponding author)

\section{Ante Bogdanić, PhD Candidate}

The Doctoral School of the Josip Juraj Strossmayer University of Osijek, Osijek, Croatia.

E-mail: ante.fmtc@gmail.com

.........

\section{Abstract}

Sport is one of the most effective promotional channels of a country that helps the country to become well-known. However, to achieve this, except the successes of athletes of one country it requires other conditions because not all sports are equally popular all over the world. Because of this, the great (global) success of an athlete is not necessarily a precondition that the athlete and country from where he or she comes is well-known because of him or her. According to the aforementioned, this paper deals with the recognition of Croatian sports and Croatian athletes at the European level. Since Croatian independence, Croatian athletes have achieved remarkable sports results and they are one of the strongest promotional channels of this small country. The purpose of this paper is to determine how strong Croatia is as a sport brand among young European students and whether Croatia is recognized at all through sport. To determine this, the authors undertook two researches during the European University Games (Zagreb \& Rijeka, 2016 - 1762 respondents and Coimbra, 2018 - 1188 respondents) using the questionnaire as a research method. The outline of the paper shows that respondents in the researches recognize Croatia as a s sports country, highly evaluated the sport element related to Croatia, and considered the Croatian football kit as being highly recognizable. The paper presents the key results.

Keywords: Croatia, brand, sport, Croatian athletes, sports promotion 


\section{Introduction}

In today's globalized world, countries, cities and regions seek different types of communication with the purpose of promoting themselves. The image of a particular country depends on different determinants such as products, national characteristics, economic environment, political environment, history and tradition (Nagashima 1970, pp. 68-74). Managing national identity and image often take place for tourism purposes, however, it is also used to strengthen the political, economic and other influences of a country that manages its own identity and image (Paliaga et al., 2010, p. 102).

Sport as an activity in modern times is present in almost all aspects of life - leisure, vacation, health, fun, occupation etc. and for a long time, it has stopped being only a "game" and has become a part of the economic activities of society (Nakić et al., 2015, p. 1). Recognizing the importance of sport, the European Commission has developed a white book where they identified the social and economic role of sports, stating that sports can serve as a tool for local and regional development, regeneration of cities or rural development (European Commission, 2007, p. 11). According to the European Commission in 2004, sports created an additional value of 407 billion euros, which is $3.7 \%$ of the GDP

of the European Union and created jobs for 15 million people or $5.4 \%$ of the work force (European Commission, 2007, p. 11).

Ahonen et al. (2016, p. 28) state that, in contemporary globalization processes, cities are trying to isolate the masses and create a positive image to attract different stakeholders (visitors, tourists, residents, etc.), and they see sport as one of the effective urban sub brands that can attract different stakeholders and create a powerful city image. It is evident that Ahonen et al. refer primarily to cities, however, their claim can be easily applied at the level of countries and regions as well.

According to Anholt (2008, p. 2), destination branding contributes to competitiveness on the global market, and to achieve competitiveness on the global market, Baxter and Kerr (2010, p. 2) emphasize the importance that destination marketing precisely determines the perceived image and attributes of a place's identity. Destination branding in the time we live is a necessity and it is far more than slogans, logos and advertising (Kaneva, 2012, p. 93). It requires much more effort, seeking creativity and originality, which provide greater recognition and a positive perception, so in that way, destinations need to offer 
quality products and services that will be distinctive in relation to the environment and competition, and which will make a certain destination recognizable as a brand based on its attributes (Skoko, Gluvačević, 2016, p. 97).

As sport is often used as an attribute of the place's identity and perceived positive image, this paper deals with the recognition of Croatian sports and Croatian athletes at the European level. Since Croatian independence, Croatian athletes have achieved remarkable sports results and they are one of the strongest promotional channels of this small country on the Adriatic Sea. The purpose of this paper is to determine which Croatian athletes and their achievements are the most recognizable and what are the differences between them in relation to the socio-demographic characteristics of respondents. Finally, the purpose of the paper is to determine how strong Croatia is as a sports brand among young European students and whether Croatia recognized at all through sport.

\section{Promotional Power of the Sport}

We live in an extremely competitive world, which means that it is necessary to invest more efforts in the fight for visitors, investors and business opportunities, and it is necessary to continuously emphasize our own advantages in order to improve our image and to retain the essential character of the destination (Aronczyk, 2013, p. 2). Destination branding and creating a positive image is a holistic development that affects a particular destination, contributing to increased awareness and relating positive associations with a destination (Rainistro, 2003, p. 44). In this sense, sports seems to be a very useful promotional tool.

In the past sport only had the purpose of entertainment, but these days, sport is considered a global and influential industry that has multiple purposes (Novak, 2006, p. 16). Without any doubt, we can talk about the global popularity of sports and also about sports as an excellent tool which promotes different products, countries, destinations etc. The popularity of an individual sport differs from country to country, however, there is certainly no country where sports are not popular and important. As such, sports can be used as a strong promotional tool in order to promote not only products and goods, but also regions, countries and cities. Thanks to the sports and athletes many countries are recognizable around the world as "sports nations". Excellent results in tennis, football, basketball, Formula 1 and so on make Spain one of these countries, just like basketball, swimming, athletics or ice-hockey make the USA recognizable as a sports nation. 
Great sporting achievements leave a mark on the world of media and on the public, and it is essential in the promotion of a country. Especially if it relates to new independent countries such as Croatia, Slovenia, Slovakia, Ukraine, Estonia, Kosovo etc. That is why every country should make efforts and investments in sport in order to improve their sporting results and promote themselves through sports. Increasing the mass of all forms of participation in sports (sport activity, observation, presence, sponsorship etc.), development of sport industry, tourism and all other activities related to sports (Selhanović, 2007, p. 97).

In this manner, sports can promote themselves in some particular country. For example, in Croatia alpine skiing was not popular until 17 years ago when Janica and Ivica Kostelić were considered to be among the best skiers in the world. In the meantime, the popularity of alpine skiing grew and there was an increased interest for alpine skiing in Croatia. The situation is similar with athletics in Croatia, tennis in Serbia or football in Iceland. In this way, a country investing in the association and infrastructure of some particular sport strengthens its promotional tool and gains a new promotional tool in sports.

Furthermore, it is not only countries that use and develop some particular sport to use as a promotional tool. Many universities do the same thing. For example, in the USA, sport has a very important role in promotion of universities. Numerous universities such as Duke, UCLA, Kentucky have a very good organizational structure for sport, which helps the university to gain a better image and to attract students. The popularity of sport at the university level in the USA is so immense that many university football or basketball matches have higher attendance than some very popular sports in Europe at the professional level.

Sport is also an effective promotional tool from the aspect of tourism. Sport tourism, including various types of sport competitions (at the professional and amateur level), visits to stadiums, sports museums etc., provide an increase in tourist arrivals and income, as also promote the destination. Visiting London long ago stopped to be focused only on visiting London Bridge, Westminster or Big Ben, but also includes visiting the football matches of Arsenal, Chelsea or West Ham, visiting their stadiums and so on. In some cities, such as Madrid or Barcelona, visiting a stadium is one of the top ten visited tourist attractions in the city. On the other hand, at the amateur level, many destinations use sporting events to strength their tourism offer and to include visitors to participate in these types of events in cycling, marathon, beach volleyball, football etc. In this way, 
destinations often use their own natural resources such as lake, river, sea, hill, mountain etc. to attract tourists and to promote the destination as a destination for an active vacation. A good example of a sporting event that promotes the destination through sport and include professionals and amateurs from all around the world is the New York Marathon, held every November.

Governments of particular countries long ago recognized the political and economic power of large sporting events and use them as a promotional and economic tool to strengthen the country image in the world and generate additional profits. In the past decades, countries and cities based their development and image strategy through organizing sports events. Large sporting events attract visitors from all over the world and have global media attention, and they are often some of the most watched television events in the world. Thanks to this, they have preconditions to become one of the most attractive promotional platforms of hosts countries or cities (Skoko, Vukasović, 2008, p. 213).

Sport definitely has many possibilities to promote countries, destinations, universities, products and goods, associations etc. Thus, it is possible to say that sport is no longer just a physical activity that requires different motor skills, which primarily relates to playing and entertainment, but is a serious promotional tool that can contribute to general and economic development.

\section{Croatian Context}

Since the beginning of $12^{\text {th }}$ century until the 1990 s, Croatia was not an independent country and different parts of Croatia were parts of other empires (only the Republic of Dubrovnik maintained its independence until the beginning of the $19^{\text {th }}$ century). So being under the Hungarians, Venetians, Austrians and Ottomans and later in a common federation with other South Slav nations (Kingdom of Yugoslavia and Socialistic Republic of Yugoslavia) has as a consequence that without independence Croatia was not recognized as a nation. In the early 1990s in Yugoslavia started were processes where several Socialistic Republics tried to gain independence. This situation resulted in turbulent times in Yugoslavia, with the aggression of Slobodan Milošević and his Serbian regime, and after Croatia declared independence in June 1991 and severed all ties with Yugoslavia, Croatia was drawn deeper into war with Yugoslavia, which started one year later. Croatia, which was known throughout the world as one of the Socialist Republics of Yugoslavia and as a 
Mediterranean tourism pearl at that time, was perceived as a victim of aggression, but it also had the image abroad as an unsafe country (Skoko, 2017, p. 16). The war, which lasted from four to eight years, depending which criteria we use, influenced the image of Croatia abroad. Therefore, the war had role in creating the new image of Croatia as new independent country and it took many years to neutralize the image ${ }^{1}$ of Croatia as a place of war (1990/1991 - 1995/1998²). Furthermore, Skoko (2017, p. 7) “points out that Croatia's fight for independence against the Yugoslav People's Army and rebel Serbs for five years and the loss of life and material destruction sustained in the war significantly hampered its development". After the war, Croatia as many other post-communist countries such as Slovenia, Slovakia, Czech Republic, Estonia, Moldova etc. was faced with the challenge of crystalizing a coherent national image within the domestic realm and also carrying the burden of transmitting a positive country image to the global community (Saunders, 2012 as cited in Skoko, 2017, p. 9). The problem for post-communist countries in the beginning was that their image was very negative in the West and they needed to make extra efforts to neutralize it (Skoko, 2017, p. 9). In that way, many European countries in transition (post-communist countries) started seeking ways to attract investments, to develop their own national brand and to present their tourism (Hall, 2004; Kaneva, 2012 as cited in Skoko, 2017, p. 10).

Fortunately for Croatia, after its war of independence, tourism in Croatia recovered quickly and until the present tourism success is increasing constantly. Croatia is definitely today a tourist country and tourism in is one of most common associations when talking about Croatia, especially in Europe. Its coast, natural beauty, gastronomy and rich heritage are unique as Croatia as a small country has great variety when it comes to landscapes, gastronomy and experiences. Consequently, in the sense of tourism, we can state that Croatia is a tourism brand because it is recognizable through it. Dwyer et al. (2017 as cited in Skoko, 2017, p. 12) speak about the phenomenon of tourism development in Croatia and the creation of a distinctive brand for Croatia so they conclude that Croatia is, in terms of tourism, a rising star; although it occupies $1.3 \%$ of EU territory and has less than $1 \%$ of the total EU population, Croatia realizes $5.1 \%$ of tourist nights in the total EU. This is also proven by the different indexes and rankings, which often position Croatia high on the list of world tourism country brands (see more in Skoko, 2017).

1 Very rarely, but still present are questions from tourist such as “Is the war over now?” and "Is Croatia safe from war?” and so on, which indicates that the image of Croatia in war is still not totally neutralized.

2 The war in Croatia lasted from 1991 to 1995, but because of the rebellions which started in 1990 and the reintegration of Eastern Slavonia in 1998, we can say that the war in Croatia lasted from 1990 to 1998, however, from 1991 to 1995 , there were war conflicts on a larger scale. 
After tourism, Croatia has many things which can promote it and make Croatia a strong country brand, however, they are not sufficiently used (or better said, not used at all) in promotion. So we can list innovators such as Nikola Tesla (alternating current/direct current inventor) and Ivan Vučetić (fingerprint inventor) or the tie ${ }^{3}$ and pen as sources of promotion (or better to say promotional tools) for the country that are not used, i.e. the place of origin of the mentioned innovators and inventions.

One of the areas where we can talk about Croatia as a brand that has the strength to promote Croatia is sport. Even though it is a small country, Croatia has great sports success in international competitions such as Olympics, world and European cups and so on. Starting from the country's independence until today, almost every year, Croatia achieves some great sporting success, which is a "big deal" in the promotion of a small country with an overall population of 4.3 million. However, the success at the FIFA World Cup 2018 in Russia, winning silver medal and winning the hearts of fans all over the world had the greatest impact on the promotion of Croatia worldwide. Furthermore, the Croatian chequered sports kit (mostly used in its football kits) are recognized as a part of the Croatian identity. After the World Cup in Russia, interest for Croatian football kits was exceptionally large and the technical sponsor of the team (Nike) had problems with the inability to produce a sufficient number for football fans all over the world.

Consequently, today, Croatian athletes have a reputation of being great and talented athletes, and some national teams such as football, handball or water polo belong to the top of world sports and are constant contenders for the top medals. Because of excellent results in tennis, handball, water polo, athletics, and with many popular football and basketball players in Croatia, there is a belief that Croatia is a sporting nation. Especially if we take numerous and constant sporting achievements in relation to the nation's population of 4.3 million and compare it with larger countries (comparing population and sport achievements) then it is possible to state that Croatian sporting achievements and Croatian sporting talents are on a pretty high level (Skoko, 2005, p. 285). At the beginning of 1990s, Croatia was fairly unknown to the world and it was often thought that Croatia and Yugoslavia were synonyms. The first signs of progress in the sense of promoting a new independent state was made by Croatian athletes and their sporting achievements at the 1992 Summer Olympics in Barcelona. Basketball players such as Dražen Petrović, Toni Kukoč and Dino Rađa or tennis player Goran Ivanišević were the

3 The tie comes from Croatia in the 17th century and after that, it became a popular fashion accessory. 
first Croatian "ambassadors" to promote Croatia. As time passed and Croatia accumulated more sporting achievements, the list of "ambassadors" become ever longer with some names such as Davor Šuker, Janica Kostelić, Ivano Balić, Luka Modrić, Sandra Perković and so on. They are also among the first mentioned associations when foreigners speak about Croatia because tourism and sports are the first things that come to mind related to Croatia and its recognizability.

In 1992, Croatia appeared for the first time at the Albertville Olympic Games and in Barcelona, where the basketball team won a silver medal. At the 1996 Atlanta Olympics, the Croatian Handball Team won a gold medal, a year later Iva Majoli Roland Garros. Tennis player Goran Ivanišević won the 2001 Wimbledon tournament. The top of alpine skiing was reached by Janica Kostelić. She was World Champion five times, World Cup winner three times, and at the Olympic Games in Salt Lake City, she won three gold and one silver medal, and in 2006, one gold and silver. Thanks to these successes, Zagreb became the host of the World Ski Cup. In 2007, Blanka Vlašić became the world champion in high jump. In team sports, the most successful were handball players - in 2003, they won the World Championship, in 2004, they took the gold medal at the Athens Olympics. Ivica Kostelić became the overall winner of the World Ski Cup, achieving a total of 26 wins. The water polo national team won the gold medal at the London 2012 Olympics, just like Sandra Perković in discus and Giovanni Cernogoraz in the trap. In 2014, Croatian sport was marked by Marin Čilićs victory at the US Open. At the summer Olympics in Rio de Janeiro in 2016, Croatia won a record number of medals (10) and number of gold medals (5) in its own history at the Olympics, making it the sixth nation in terms of success at the Games and the second best nation in Europe by number of medals won per capita. Sandra Perković won a second Olympic gold in Brazil 2016, the Moscow World Cup in 2013, all the Diamond Leagues from 2012 to 2016 and even four European championships. Luka Modrić, as a Real Madrid footballer, was among the best players in the world in 2016 and 2017.

Croatia's experience proves how a new independent country can be recognizable to the world through the sport. To prove the value of Croatia's success used will be data of how many Summer Olympics medals Croatian athletes won and it will be compared with other countries in general. In the last 25 years, Croatia has won 33 medals and over the last 15 years, Croatia belongs to the top 20 countries worldwide by the medals per capita criterion. In general, Croatia with 33 medals has an average score of 130.000 citizens per medal, placing Croatia in $39^{\text {th }}$ place. If we keep in mind though that Croatia has competed only in 
the past 25 years, the final ranking on the list is even better. Croatia's sporting success at the Summer Olympics is presented in Table 1.

Table 1. Medal per capita - Summer Olympics (1992-2016)

Source: Medals per capita (2016) - Olympics Glory in Proportion

\begin{tabular}{|c|c|c|c|c|}
\hline SuMMER Olympic Games & $\begin{array}{l}\text { No. of } \\
\text { medals }\end{array}$ & World rank & $\begin{array}{l}\text { Average medal per } \\
\text { capita }\end{array}$ & $\begin{array}{c}\text { European } \\
\text { rank }\end{array}$ \\
\hline 2016 Rio de JaneIro & 10 & 6 & 422.440 & 2 \\
\hline 2012 London & 6 & 15 & 715.102 & 8 \\
\hline 2008 Beijing & 5 & 19 & 858.122 & 11 \\
\hline 2004 Athens & 5 & 16 & 895.129 & 11 \\
\hline 2000 Sydney & 2 & 41 & $2,214,536$ & 31 \\
\hline 1996 Atlanta & 2 & 33 & $2,210,369$ & 23 \\
\hline 1992 Barcelona & 3 & 24 & $1,560,362$ & 13 \\
\hline Total & 33 & 39 & 130.018 & 24 \\
\hline
\end{tabular}

According to this criterion and if we include sport successes outside the Summer Olympics, we can state that Croatia definitely is "material" for becoming a sport brand, however, the question is whether it is truly recognized as a sport brand.

\section{Survey Methodology}

This survey deals with recognition of Croatia, Croatian sports and sports achievements as part of a comprehensive survey, in which the habits of young students from Europe during the European University Games 2016 and 2018 are explored. Consequently, the survey consists of habits of young students, such as how often they watch sports, reasons for watching, how they perceive sponsors in sports, and most importantly, how and in which way they perceive Croatia and Croatian sport. The survey was prepared in July 2016 in the cities of Zagreb and Rijeka (both Croatia) among more than 5000 students and it includes 1762 respondents. The survey conducted in July 2018, in Coimbra (Portugal), was carried out among 3500 students and includes 1188 respondents. Both surveys lasted for 14 days, during which the interviewers collected data from student participants. The interviewers collected data at the most frequent locations during the competition, and in both cases, it was near the university restaurant. 
The 2016 questionnaire included 37 different questions during the European University Games 2016 and the 2018 questionnaire included 17 questions (both open and closed ended). The 2016 questionnaire can be divided in three main parts: recognition of Croatia, recognition of Croatian sport \& sports advertising. The 2018 questionnaire was shorter than the previous one and it included only parts related with the recognition of Croatian sport and sports advertising. The majority of questions from the second questionnaire can also be found in the first survey from 2016, as it was the intention of the authors to have continuity. Finally, there are no significant differences between the questions in these two questionnaires, except that the second questionnaire excluded a significant part of the first questionnaire. As far as the research process itself is concerned, in both cases it was identical.

In both questionnaire, respondents from over 45 different countries participated (49 in 2016, 46 in 2018). The questionnaire's strength and importance lies in the fact that it includes students from all around Europe who are voluntarily involved in this sporting event. In addition, this sample assumes that it consists of a population of young people who are in the process of acquiring higher education, who have an interest in sports and travel, and who are, in a way, decision makers in the environment in which they are located. Therefore, on the basis of these parameters, this sample can certainly be considered as representative in the European student population.

The purpose of survey was to establish to what extent is Croatia recognizable through sport, whether Croatia and some of its athletes and sport clubs can be considered as European sports brands. Furthermore, to understand and relate the recognition of Croatian sport, the habits of respondents which are related to sport will be shown.

\section{Survey Results}

In the survey, explored were the associations of respondents to Croatia and the respondents needed to write down up to three associations. Both surveys (2016 and 2018) show that sports play an important part in it. The biggest difference between the two surveys related to this question was the respondent rate, where in 2016, respondents wrote down an average of 2.58 associations, while in 2018 , the average rate was 0.91 association per respondent. In both surveys, the most common association was the Adriatic sea and coast with $60.3 \%$ in 2016 and $16.8 \%$ in 2018 , which was followed by the association of sport and 
sporting events with $29.4 \%$ in 2016 and $21.4 \%$ in 2018 . The minimum difference between the two survey was connected with the highly positioned association of Croatian athletes with $16.2 \%$ in 2016 and $15.4 \%$ in 2018. It is interesting to mention that in the 2018 survey, Luka Modrić was mentioned 9.9\% as an association of Croatian athletes.

As for other associations, the most common are sun, Croatian cities and other places, food and drink, Croats, as well nature and natural beauty. With the obtained results, it can be concluded that Croatian sports and athletes are very important and recognizable to associated them with Croatia. The list of the most common associations related with Croatia is shown in Figure 1.

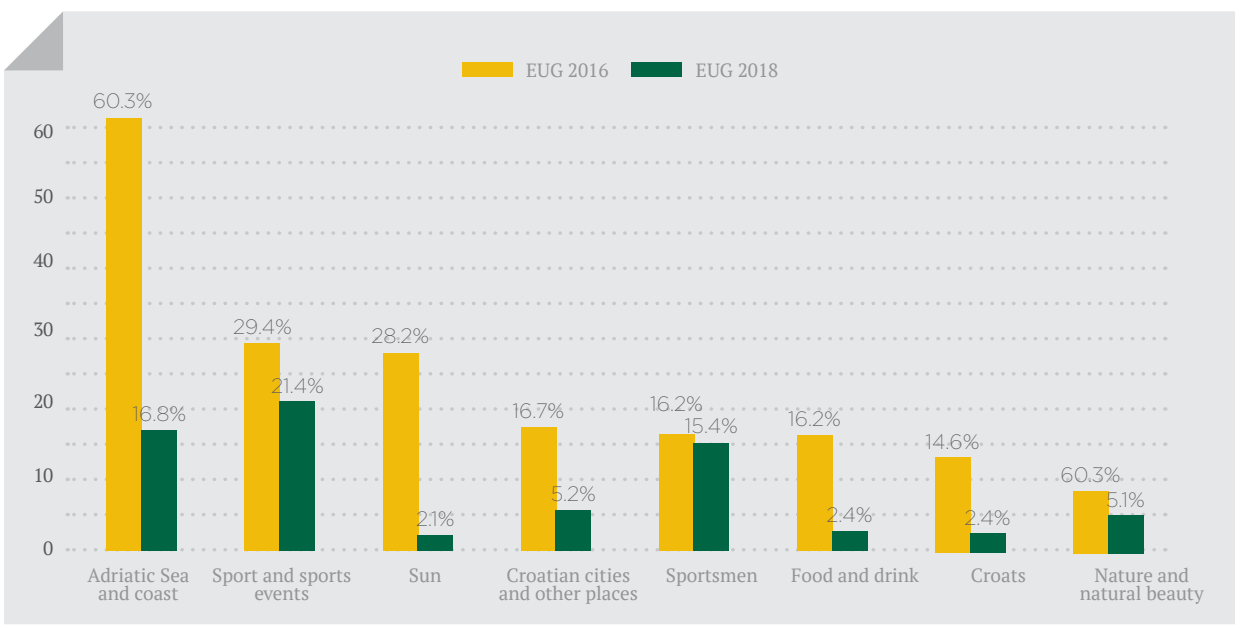

Figure 1. Associations related with Croatia

One of the survey questions deals with knowledge of how strongly respondents evaluate different elements on list with Croatia. They need to evaluate each element with a score from 1 to 10 , whereby 10 is the highest score. The survey results show that sun and sea (8.69 / 7.97), tourism (8.06 / 7.69), natural beauty (7.99 / 7.65), sport (7.73 / 7.61) and fun (7.72 / 7.18) are the highest evaluated elements of Croatian identity in both the 2016 and the 2018 surveys. The chequered identity, as seen on Croatia's coat of arms and national football team kits, was scored with a 7.0 in 2016 and a 6.98 in 2018. These results also imply that sports play an important part as one of highest evaluated elements of Croatian identity. On the other hand, Croatian gastronomy was scored with a 6.11 in 2016 and a 6.01 in 2018, which shows that Croatian cuisine is still not recognizable outside Croatia, 
despite the fact that it is a rich and beloved gastronomy by tourists from abroad. There is no scientific explanation why all scores in the 2018 survey are lower than the results shown in the 2016 survey, however, the author supposes that this is because the respondents in the 2016 survey were more influenced by Croatia and its elements of identity, probably due to the influence of Croatia as the host of the competition in 2016.

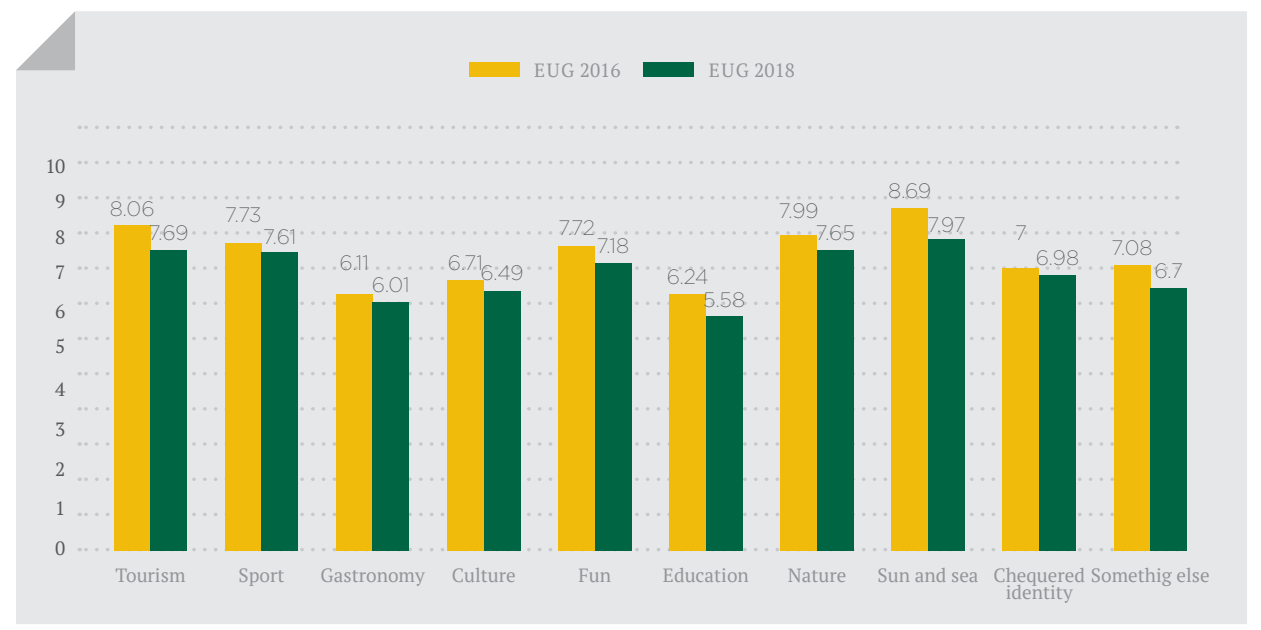

Figure 2. Elements of Croatian identity

Talking about the chequered identity and the Croatian national football team, they are recognizable through the chequered first kit, which consists of red and white squares. One of the questions deals with it in a way to establish how strongly respondents agree with the statement that the Croatian chequered identity on sport kits is recognized all over the world. The survey results show that, in $2016,64.7 \%$ of respondents agree completely or agree with this statement, while in $2018,56.5 \%$ of respondents provided the same statement. On the other hand, only $8.3 \%$ or respondents in 2016 did not agree with this statement, as well 7.5\% in 2018. In between, neither agree nor disagree, there are $19.3 \%$ of respondents in 2016 and $28.4 \%$ in 2018. Therefore, it can be concluded that the Croatian chequered identity is pretty much recognizable in the world. 


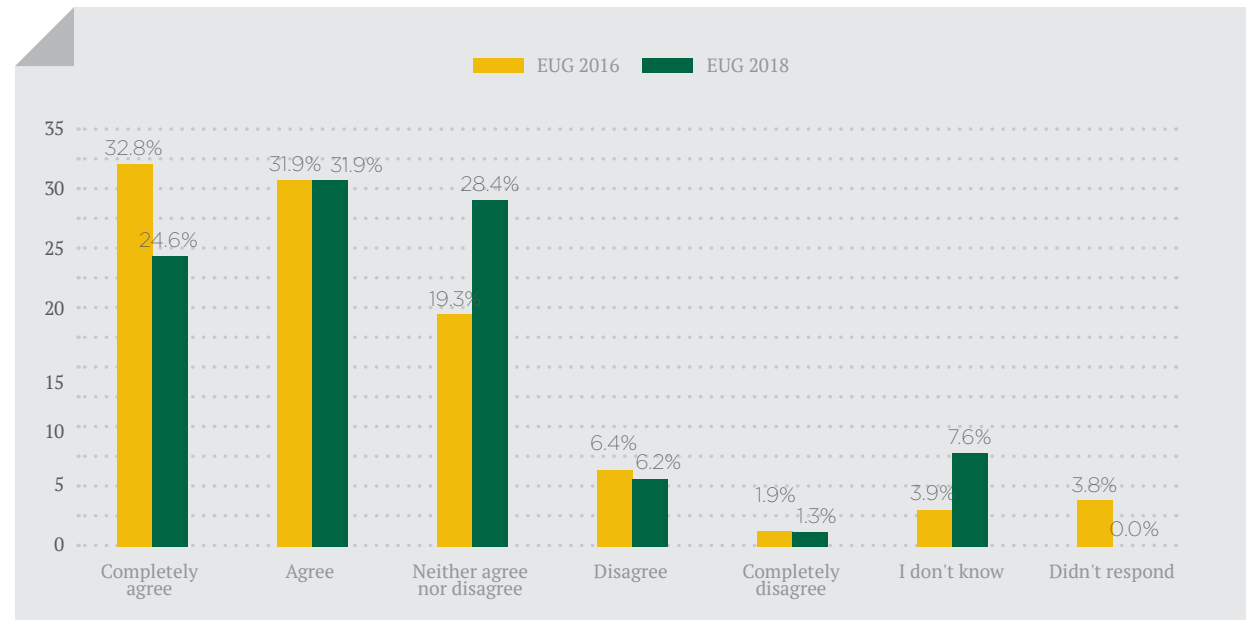

Figure 3. Recognition of Croatian football kit

In the survey, respondents needed to list up to three athletes they know are Croatian athletes. The results of the survey show that football player Luka Modrić from Real Madrid is the best-known Croatian athlete (37.5\% in 2016 and 59.1\% in 2018). He is followed by Barcelona star Ivan Rakitić (18.1\% in 2016 and 32.7\% in 2018), former basketball player Dražen Petrović (13.2\% in 2016 and 2.9\% in 2018) and former ski champion Janica Kostelić (13.0\% in 2016). It is interesting that former football player and Golden Boot winner Davor Šuker is in 13th place with 4.0\% (2016), as it is believed that he is among the five most recognizable Croatian athletes. The list of best-known Croatian athletes consists of athletes not only from football, basketball and skiing, but also from tennis, handball and athletics. Also, it is easy to notice that the Croatian football success at the FIFA World Cup 2018 in Russia had a strong influence on respondents' answers, while many of football stars in 2018 were not mentioned by respondents in the 2016 survey or they achieved less than $1 \%$. As a result, there is an obvious domination of football athletes in the 2018 survey. In Table 4, there is detailed list with the best-known Croatian athletes. 


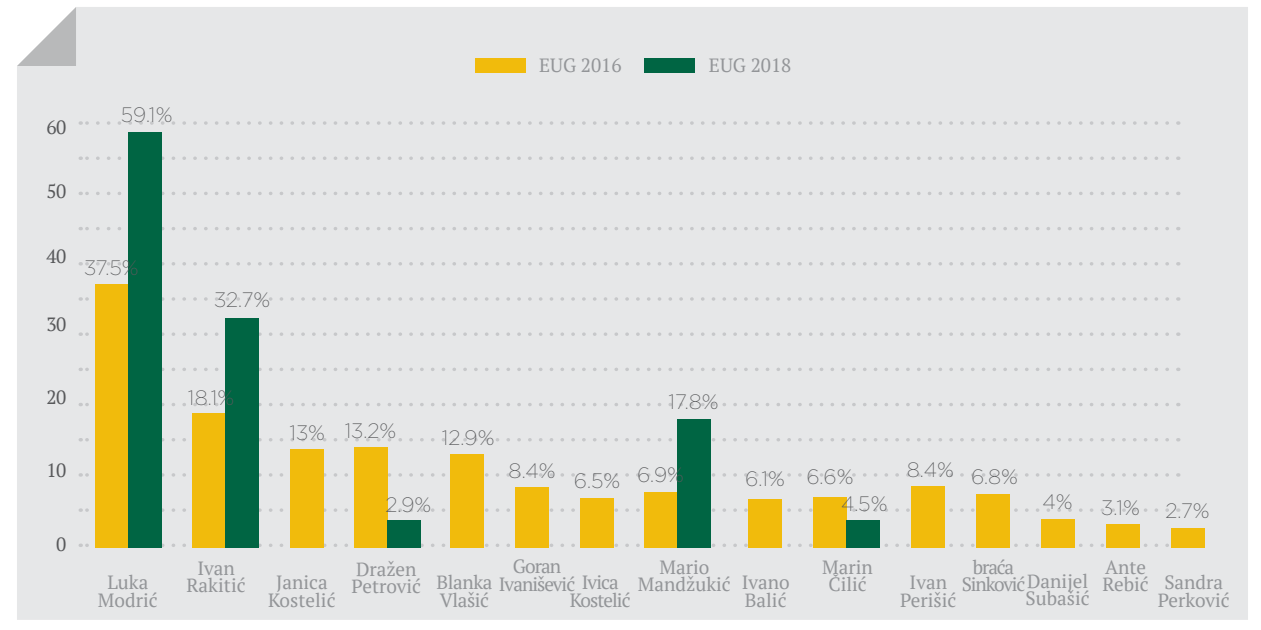

Figure 4. Most recognizable Croatian athletes

Respondents were asked to evaluate from 1 to 5 how strongly is Croatia recognized through sport. About $51.0 \%$ (2016) and $73.5 \%$ (2018) of respondents evaluated it with the highest scores (4 and 5), while only 8.2\% (2016) and 4.2\% (2018) of respondents evaluated it with the lowest scores (1 and 3). Almost every fifth respondent (19.5\%) in 2016 did not respond to that question, while in 2018 , there was $4.5 \%$ who did not provide an answer.

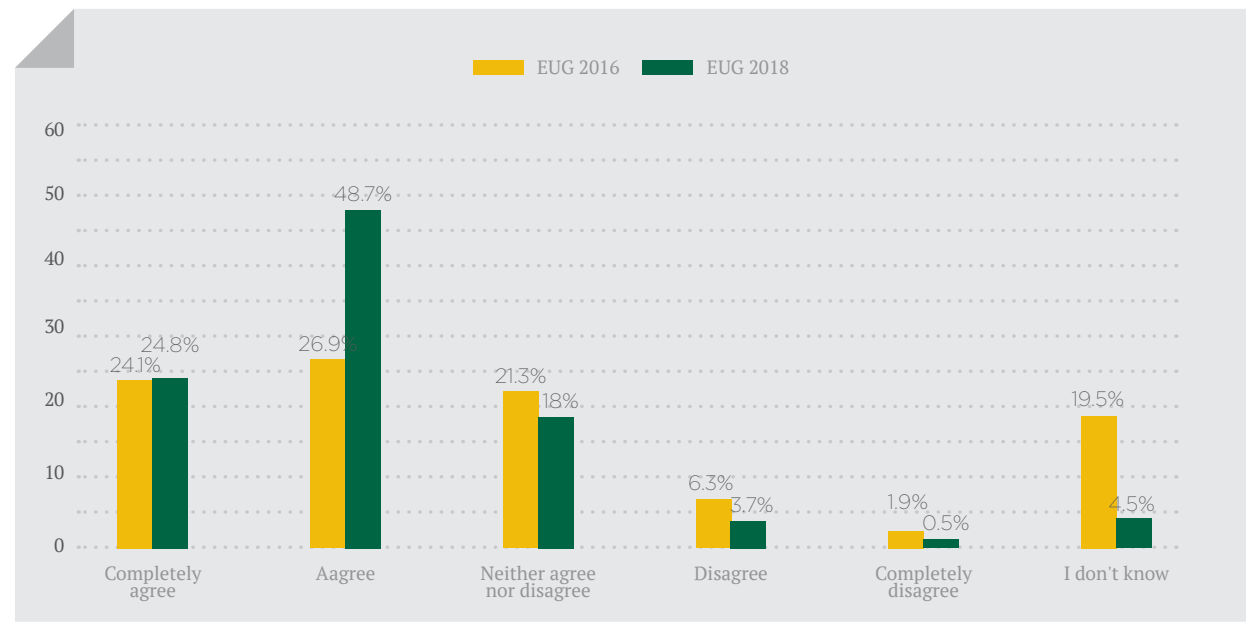

Figure 5. Recognition of Croatia through sport 
One of the questions in both surveys dealt with the greatest Croatian sports success. The survey from 2016 has a close-ended question with eleven offered responses. According to the respondents in 2016, Janica Kostelić's three gold medals and one silver medal during the 2002 Winter Olympics in Salt Lake City is considered the greatest Croatian sport success with $25.4 \%$. The second greatest success is Goran Ivanišević winning Wimbledon in 2001 (19.3\%), which is followed by the football bronze medal, won at the FIFA World Cup in France 1998 (16.8\%).

In 2018, respondents were asked to answer the same question, but this time the question was with an open-ended response. Responses were not so precise, mostly focusing on sport and not to specific sport success. For most of the respondents in 2018 (60.5\%), winning the silver medal at the FIFA World Cup 2018 in Russia was the greatest sport success for Croatian sport. All in between are indefinite sporting successes (football with $13.9 \%$, water polo $3.7 \%$, handball $2.1 \%$ and basketball $2.0 \%$ ), except the rowing gold medal from the 2014 Olympics won by the Sinković brothers.

A detailed list with the greatest Croatian sport successes is shown in Figure 6.

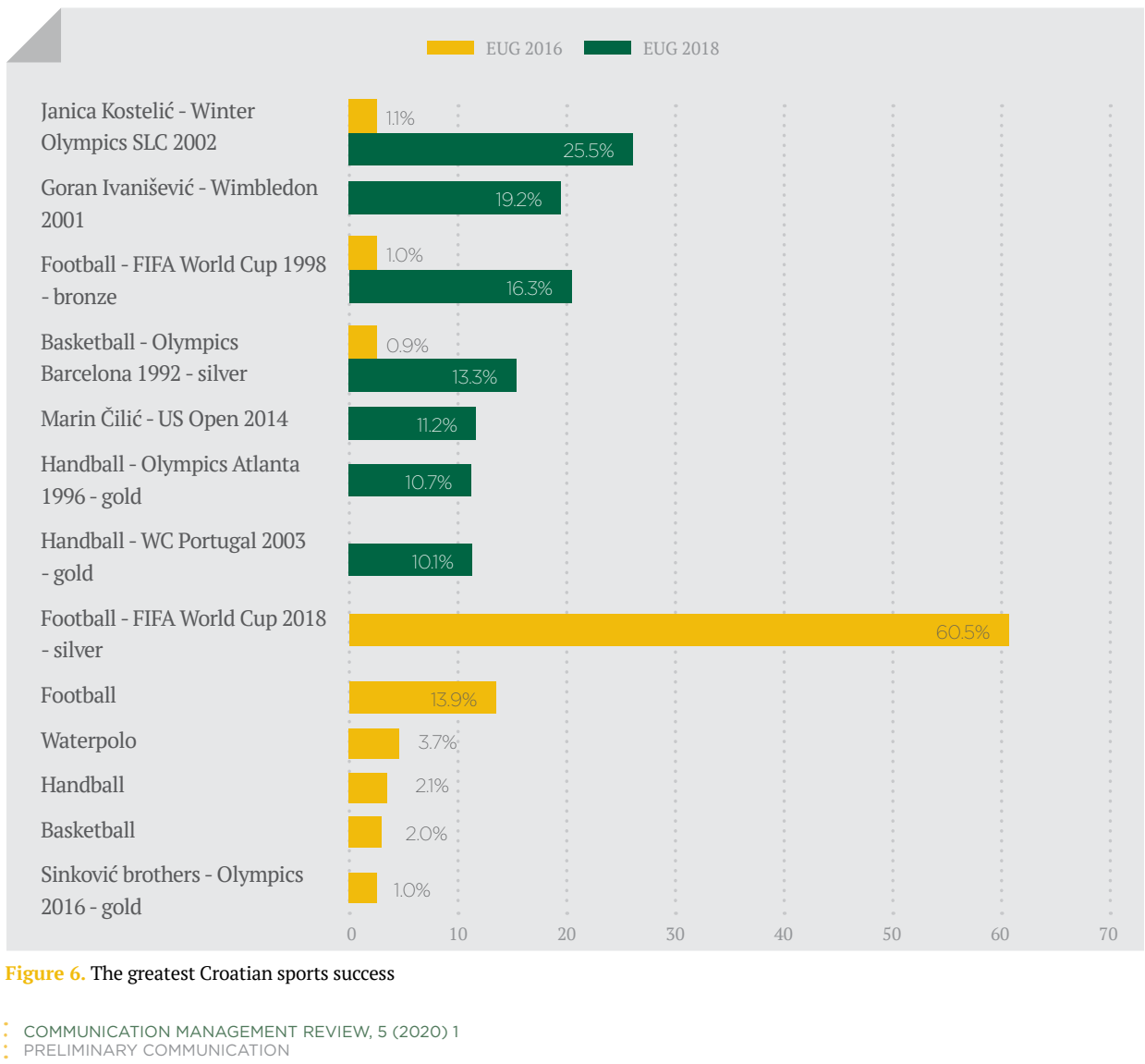


Furthermore, being a famous athlete is not enough to be well known in the world and to promote your own country and the author was looking to find a way to find an answer on that question. In 2016, Britain's Olmypic gold medal winner Mo Farah was used and in 2018, one of the most dominant female athletes (Croatian athlete Sandra Perković) to prove that sporting success on its own is not sufficient; there is a need to manage the image of the individual athlete.

Figure 7 shows that, in 2016, less than half of respondents were familiar with what country Mo Farah competes for, and it is Great Britain (46.9\%). More than one quarter of respondents thought he competed for Kenya (27.4\%) as running is an association with that country. Almost every seventh respondent (14.9\%) did not know the answer.

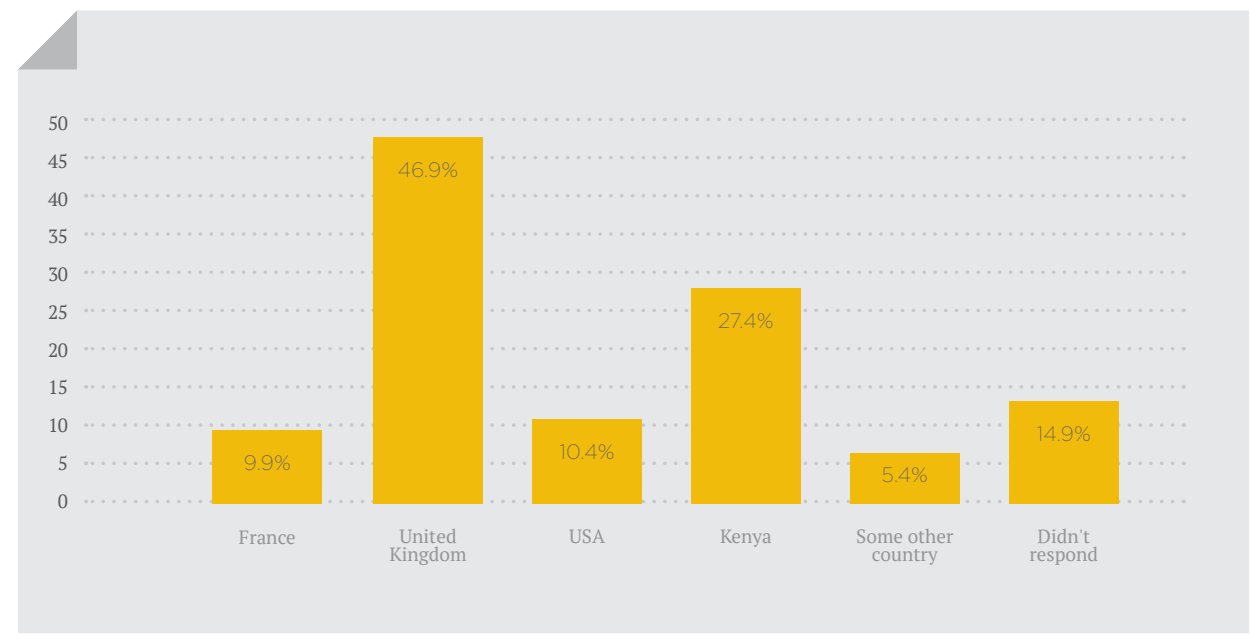

Figure 7. Mo Farah and his country

Two years later, in 2018, the name of famous Croatian athlete Sandra Perković was used in the question to prove the same statement as in 2016. Currently, one of the most dominant female athletes was recognized by every fifth respondent (19.4\%). Almost half of respondents (46.4\%) did not know the sporting discipline she competes in. 


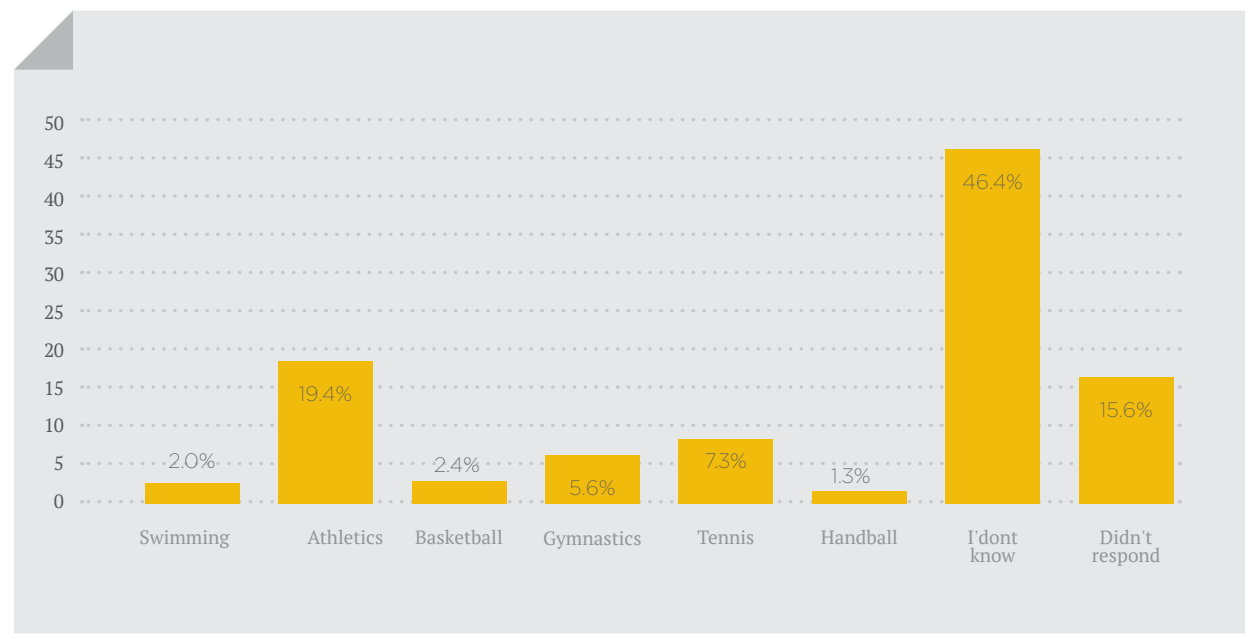

Figure 8. Sandra Perković and sporting discipline

\section{Conclusion}

As it is written in the introduction, sport plays an important role in contributing to promote some country, city or region. For this reason, more and more countries are using sport as one of the promotional tools to gain a positive image worldwide. Sporting events and sporting achievements at major events are some of the most used channels for this. Croatia, as a small country, does not have that power and resources to organize major sporting events such as the Olympics or the FIFA World Cup, however, in the past, it was host of world and European championships in handball, basketball, and it also organizes very popular tennis and alpine skiing events. For Croatia, it is more important that it has a great pool of sport talents, which over the last three decades provided major sporting achievements, and winning the silver medal at the last FIFA World Cup is the best evidence of this. However, even if it gains major sporting achievements, the question is whether Croatia is perceived as a sporting nation or not, is Croatia a sport brand? All these questions have led the authors to conduct surveys on Croatia's recognition as a sport nation. These two surveys were a great opportunity to conduct research among 
the European student population, who represent the European young intellectual elite and future opinion makers. Aware of the limitations of such a narrow sample (student population), the authors approach the sample as the basis for future surveys. Furthermore, the high proportion of respondents in Croatia (2016 survey) and the major Croatian sports success such as the FIFA World Cup final in 2018 (2018 survey) certainly partially affected the survey results.

Consequently, after the survey was conducted, we can conclude that Croatia is a sport brand among European students. First of all, among the most common association related with Croatia, after sea and coast, sport and athletes are the most common associations. Therefore, these associations definitely make Croatia a sport brand. Analysing data referring to elements of Croatian identity, tourism, natural beauty, sun and sea are shown as the strongest elements of Croatia's identity, and they were followed by sport. This shows us that Croatian identity is first perceived through tourism and "tourism products" such as natural beauty, sun and sea, and after that with the element of identity such as sport. Also, the surveys proved that the Croatian chequered identity on sport kits is recognizable throughout the world.

Furthermore, the best-known Croatian athletes are those who are still active, such as Luka Modrić and Ivan Rakitić. However, the list of the best-known Croatian athletes contains many active athletes, as well retired ones, which can serve to conclude that many retired Croatian athletes are still present in the perception of respondents.

Therefore, according to these results and others which are shown in the section Survey Results, we can conclude that Croatia is perceived as a sport nation, however, there is still a lot of room to become more recognizable and to gain more benefits through sport. However, this step is up to Croatian institutions who need to provide a strategy, logistic and structural infrastructure to progress in this regard. Therefore, these two surveys, as well as future surveys that will be done on this topic, can be helpful, using some other research methods such as interviews and focus groups. 


\section{Reference List}

- Ahonen, A., Lamsa, J., Mero, A., Karimaki, A. (2016). Sport city branding of a mid-sized city in Finland. Acta Turistica, 28 (1), 27-48.

- Anholt, S. (2008). Place branding: Is it marketing or is it not?. Place branding and public diplomacy, 4 (1), 1-6.

- Aronczyk, M. (2013). Branding the Nation: The Global Business of National Identity. Oxford: Oxford University Press.

- Baxter, J., Kerr, G. (2010). The meaning and measurement of place identity and place image. European Regional Science Association. Retrieved from: https://www.academia.edu/1596443/The_Meaning_and_Measurement_of_Place_Identity_and_ Image?auto=download. September 9, 2017.

- Kaneva, N. (2010). Branding Post-Communist Nations: Marketizing National Identities. New York: Routledge.

- Medals per capita (2016). Olympics Glory in Proportion. Retrieved from: http://www.medalspercapita.com/\#medals-percapita:2012. September 9, 2017.

- Nagashima, A. (1970). A Comparison of Japanese and U.S. Attitudes Toward Foreign Products. Journal of Marketing, 34 (1), 68 -74.

- Nakić, J., Stilin, A., Tomljenović, Lj. (2015). Istraživanje interesa za razvoj poduzetništva u sportu. Zbornik Veleučilišta u Rijeci, 3 (1), 1-14.

- Novak, I. (2006). Sportski marketing i industrija sporta. Zagreb: Mailing.

- Paliaga, M., Franjić, Z., Strunje, Ž. (2010). Methodology of valuation of city brands. Ekonomska istraživanja, 23 (2), $102-111$.

- Rainisto, S. (2003). Success Factors of Place Marketing: A Study of Place Marketing Practices in Northern Europe and the United States. Helsinki: Institute of Strategy and International Business.

- Selhanović, D. (2007). Sport - najsnažniji promidžbeni adut. Medianali, 1 (1), 95-102.

- Skoko, B. (2005). Hrvatska: identitet, image i promocija. Zagreb: Školska knjiga.

- Skoko, B. (2017). Communication Strategies and Branding Attempts of Selected Countries Created upon the Disintegration of the Former Yugoslavia. Sociologija i prostor, 55 (1), 5-31.

- Skoko, B., Gluvačević, D. (2016). Države kao turistički brendovi: kreiranje, upravljanje i vrednovanje. Medijske studije, 7(13), 78-101.

- Skoko, B., Vukasović, I. (2008). Organiziranje međunarodnih sportskih događaja kao promotivni i ekonomski alat države. Tržište, 20 (2), 211-230. 


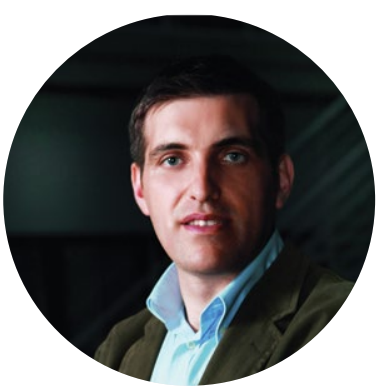

Božo Skoko

Božo Skoko, $\mathrm{PhD}$, is professor at the Faculty of Political Science of the University of Zagreb, where he is head of the Public Relations postgraduate study. The areas of his scientific research include: communication, international relations, national identity and image and branding destination. He is a longtime strategic communications consultant and co-founder of Millenium promocija, the leading Croatian public relations agency. He is a former journalist and editor at the Croatian Radiotelevision (HRT). He has published seven books (Understanding Croatia, Amazon, 2018.; What are Croats like, Fokus, 2016.; Croatian Greats, Večernji list, 2014.; Croatia and Its Neighbors - How Croatia Is Perceived in Bosnia and Herzegovina, Montenegro, Macedonia, Slovenia and Serbia, AGM, 2010; The State as a Brand, Matica hrvatska, 2009.; Croatia - Identity, Image, Promotion, Školska knjiga, 2004 and 2005), as well as Handbook for Understanding Public Relations, MPR, 2006. and over seventy scientific papers on public relations, the media and managing the identity and image of Croatia.
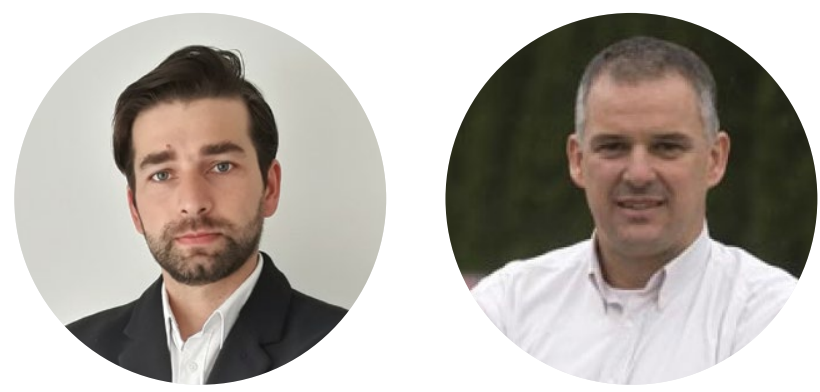

Dejan Gluvačević

Ante Bogdanić

Dejan Gluvačević, $\mathrm{PhD}$, is private entrepreneur and external associate at Faculty of Political Science of the University of Zagreb at Department of Strategic Communication. His scientific research includes areas of destination branding, national identity and image, communication in tourism and international relations. Professional experience gained working as a journalist and as a practitioner in marketing and PR agencies. He took a part in several international scientific conferences and he is the author of nine scientific papers on destination branding, tourism communication and crisis communication in tourism.
Ante Bogdanić is a $\mathrm{PhD}$ Candidate at Doctoral School of Communication Studies at the University of Osijek. For many years, he owns a marketing agency where he started numerous projects in the area of promotion and education. His area of scientific research includes: sports promotion, country branding and communication in sports. He participates in the organization and realization of a comprehensive research related to the sport branding, as such as European University Games (2016, 2018). He took a part in several international scientific conferences and he is an author of few scientific papers related to the mentioned scientific areas. 